PRIVAS-BRÉAUTÉ, Virginie - Drama activities to create a positive language learning environment...

Para lá da tarefa: implicar os estudantes na aprendizagem de línguas estrangeiras no ensino superior. Porto: FLUP, 2019, pp. 292-309 DOI: https://doi.org/10.21747/9789898969217/paraa16

\title{
Drama activities to create a positive language learning environment in higher education
}

\section{Virginie Privas-Bréauté}

ATILF - University of Lorraine / CNRS (UMR 7118), Nancy, France virginie.privas-breaute@univ-lorraine.fr

\begin{abstract}
In Freedom to learn, Rogers (1969) presents the results of studies that shed light on the positive effects of teachers' empathy on learning environments. Rogers explains that in providing a positive learning environment by being emotionally involved, teachers invite their students to learn better and be more motivated. The empathetic attitude of teachers is one of the conditions that motivates students, but it is not enough (Viau, 2009). Relying on the neuroscientific enaction paradigm (Varela, 1993, 1996), Aden (2017) studies the pedagogical value of drama in language learning and shows how emotions, body and mind all contribute to language acquisition through the emergence of empathy among the participants. Further research on the cognitive development of language learners in higher education shows that drama facilitates the development of linguistic and general competences. In this paper, we aim to demonstrate how, from psychological and neuroscientific standpoints, drama activities can create positive language learning environments and facilitate learning.
\end{abstract}

Keywords: drama, embodied cognition, emotions, enaction, English learning/teaching, neuroscience

\section{Resumé}

Dans Liberté pour apprendre, Rogers (1969) présente les résultats d'études mettant au jour les effets bénéfiques de l'empathie des enseignants sur les environnements d'apprentissage. L'auteur explique qu'en étant impliqués émotionnellement, les enseignants créent des environnements propices aux apprentissages et permettent aux apprenants d'être plus motivés, et ainsi de mieux apprendre. L'attitude empathique des enseignants est un facteur de motivation pour les apprenants mais il n'est pas suffisant pour optimiser l'apprentissage (Viau, 2009). Aden (2017) s'est appuyée sur le paradigme neuroscientifique de l'enaction (Varela, 1993, 1996) et a étudié l'empathie ressentie par 
PRIVAS-BRÉAUTÉ, Virginie - Drama activities to create a positive language learning environment... Para lá da tarefa: implicar os estudantes na aprendizagem de línguas estrangeiras no ensino superior. Porto: FLUP, 2019, pp. 292-309 DOI: https://doi.org/10.21747/9789898969217/paraa16

les apprenants lors de séances pédagogiques impliquant des jeux théâtraux au sein de leurs cours de langue. Elle montre à quel point les émotions et le corps accompagnent l'esprit lorsqu'il s'agit de l'acquisition/ apprentissage d'une langue. De plus amples recherches scientifiques portant sur le développement cognitif d'apprenants de langues dans l'enseignement supérieur témoignent de la valeur pédagogique du jeu théâtral lorsqu'il s'agit de faire acquérir des compétences langagières et générales. Cet article propose d'adopter une approche psychologique et neuroscientifique pour démontrer que les activités théâtrales peuvent créer des environnements d'apprentissage bienveillants et faciliter l'apprentissage des langues.

Mots-clés: apprentissage/enseignement de l'anglais, bienveillance, cognition incarnée, émotions, enaction, jeu théâtral, neurosciences

\section{1 - Introduction}

The Common European Framework of Reference for Languages (CEFR, 2001) recommends language learners to be at the center of their learning. It puts the stress on inviting students to learn autonomously, complete tasks and encourages teachers to let learners become actors in their own learning. These indications have led language teachers to introduce drama and drama activities to teach English and consider them as valuable pedagogical devices so that learners progressively become actors in their English learning. Drama and drama activities facilitate learning in so much as they enable the accomplishment of tasks and resolution of problems. Yet, if we think about how to "go beyond the task" in class, we can reflect not only upon all the elements that come before and after the activities but also upon the relationship between students and teachers and among students themselves. This is how the question as to what extent introducing drama in the language class can create a positive language learning atmosphere has arisen.

After explaining how, from both psychological and neuroscientific complementary standpoints, empathy and embodied cognition help understand why drama can create positive language learning environments, two experiments carried out with different profiles of French students learning English will be described. Through these descriptions, we will underline the impact of drama activities on the development as well as the improvement of linguistic and general competences of language learners and suggest a model of learning/teaching languages based on drama. Eventually, 
PRIVAS-BRÉAUTÉ, Virginie - Drama activities to create a positive language learning environment...

Para lá da tarefa: implicar os estudantes na aprendizagem de línguas estrangeiras no ensino superior.

Porto: FLUP, 2019, pp. 292-309

DOI: https://doi.org/10.21747/9789898969217/paraa16

observations on the ground as well as the opinions of students conveyed through questionnaires will enable us to pinpoint the strengths and weaknesses of this device.

\section{2 - Research aims}

One of the main challenges of foreign language teachers is to have their students speak the target language spontaneously. Very often, only the best students and the ones who feel more at ease with oral communication in a foreign language end up speaking naturally. Unfortunately, this even happens in English for specific purposes (ESP) classes where the foreign language they are taught is meant to train them to speak foreign languages at work, which should give the language course a supplementary motivational objective. Among the reasons why students dare not communicate orally is linked to negative emotions they feel such as stress, anxiety, fear. In Principles and Practice in Second Language Acquisition, Krashen insists on the impact of the context and situations on the affective filter when processing the input of the target language:

Those whose attitudes are not optimal for second language acquisition will not only tend to seek less input, but they will also have a high or strong affective filter - even if they understand the message, the input will not reach the part of the brain responsible for language acquisition, or the language acquisition device. (Krashen, 1982, p. 31)

Based on this, studies (Horwitz, Horwitz \& Cope, 1986; Arnold, 1999; Schumann, 1994) have shown that bad emotions felt within the class hinder language acquisition. On the contrary, positive emotions facilitate language learning. Therefore, a teacher's aim should be to help students relax and lessen the bad feelings and emotions they feel when they must learn and speak English. Drama activities have thus been introduced so as to try to create a positive atmosphere within the classroom and permit learners to overcome any bad feelings and emotions they might have. We assumed that introducing this device will then facilitate speaking and learning the foreign language. Our research thus aims to demonstrate that drama and drama activities introduced in the language classroom in higher education is a device that creates a positive language learning atmosphere and facilitates English learning. Not only does it rely on a psychological approach underlining the crucial role of the teacher in impacting the emotions and feelings of their students but it also falls within the paradigm of enaction inscribed in the theories of embodied cognition. 
PRIVAS-BRÉAUTÉ, Virginie - Drama activities to create a positive language learning environment... Para lá da tarefa: implicar os estudantes na aprendizagem de línguas estrangeiras no ensino superior. Porto: FLUP, 2019, pp. 292-309 DOI: https://doi.org/10.21747/9789898969217/paraa16

\section{3 - Theoretical framework}

\section{1 - Psychological approach}

In Freedom to learn, the American psychologist Carl R. Rogers presents the results of studies that shed light on the positive effects of teachers' attitudes on learning environments. The author explains that creating a positive learning environment by being emotionally involved, teachers invite their students to learn better and be more motivated.

Rogers trusts humanity, especially when men - and women - can be free and creative. These are two conditions that, to him, can enable teachers to develop their personality and then help students develop on their own and be self-confident. As for the learning environment, the author then asserts that there should exist an excellent quality of interpersonal relationships based on the behavior of teachers, whom he calls "facilitators", and gives a list of what teachers should be and how they should behave. He first says that teachers should be real/congruent (that is to say "be themselves") and always bear a positive outlook (which he calls "prizing") on their students, care for them, be confident in who they are and what they can achieve and respect them (Rogers, 1969, p.184). Confidence based on empathetic listening is what teachers should bring to the group of students they have in front of them so as to enable them to develop and free their potential. This is what creates a good learning environment.

However, such an environment also relies on the degree of agentivity of the students, especially in the context of student-oriented approaches to language learning/teaching. The benevolent attitude of teachers is one of the conditions that motivates students to learn, but it is not the only one (Viau, 2009). Students should also prove to be motivated, involved, concerned and willing to progress. These are emotional conditions to create a positive learning atmosphere and, subsequently, to facilitate learning.

Neuroscience and neurolinguistics (Paradis, 1994) have recently shed the light on discoveries that have come to scientifically confirm the intuitions teachers had about the reasons why positive emotions are closely linked to better language learning.

\section{2 - Neuroscientific standpoint}

The neuro-biologist Francisco Varela focuses on the ways human beings access cognition and studies the place of language in this context. He writes that languages are the tools that lead people to meet so as to make meaning emerge. His scientific research in neuroscience has led him to develop the paradigm of enaction, falling within the theories of embodied cognition and relying upon three cornerstones: participatory 
PRIVAS-BRÉAUTÉ, Virginie - Drama activities to create a positive language learning environment...

Para lá da tarefa: implicar os estudantes na aprendizagem de línguas estrangeiras no ensino superior. Porto: FLUP, 2019, pp. 292-309 DOI: https://doi.org/10.21747/9789898969217/paraa16

structural coupling, individual learning paths, and emergence of meaning. For Varela, people possess autopoietic individual strategies to acquire and learn languages, and when they meet, they make meaning emerge (Varela, 1993, p. 91). The context has an important role to play in this emergence of meaning as he writes in Invitation aux sciences cognitives:

La plus importante faculté de toute cognition vivante est précisément dans une large mesure, de poser les questions pertinentes qui surgissent à chaque moment de notre vie. Elles ne sont pas prédéfinies mais enactées, on les fait émerger sur un arrière-plan et les critères de pertinence sont dictés par notre sens commun, d'une manière toujours contextuelle. (Varela, 1993, p.91)

For the scientist, languages are not merely used to pass on information. They are a means to couple (Varela's word) individuals from a same species for action coordination.

Varela says that pure reasoning does not exist and explains that one of the pitfalls in which people lure themselves when it comes to language acquisition - among other types of learning - is to think that reason and emotions are two separate entities. On the contrary he asserts that emotions - including the hormonal system - and reasoning are constitutive of the structure of a body. Reasoning is always affected by emotions. For Varela, emotions are part and parcel of the learning process:

L'intervention de l'implication du corporel et de l'émotionnel dans les processus d'apprentissage qui fait justement l'émergence du nouveau, c'est essentiel parce que sinon ça ne s'enracine pas dans un travail à dimension structurelle du corps et donc c'est un apprentissage superficiel (qui) passe très vite à une espèce de classement d'oubli d'abstraction. (Trocmé-Fabre, 1994)

Along those lines, he considers that the body/mind continuum in learning - including language learning - enables long-term memorization. If thought is not separated from the body and emotions, then thought and speech are incorporated, they are incarnated, and cognition is enacted.

In Drama Techniques in Language Learning, Maley and Duff explain that language acquisition involves body, emotions and mind to show that drama activities facilitate learning:

Language is not purely an intellectual matter. Our minds are attached to our bodies, and our bodies to our minds. The intellect rarely functions without an element of emotion, yet it is so often just this element that is lacking in teaching 
PRIVAS-BRÉAUTÉ, Virginie - Drama activities to create a positive language learning environment...

Para lá da tarefa: implicar os estudantes na aprendizagem de línguas estrangeiras no ensino superior. Porto: FLUP, 2019, pp. 292-309 DOI: https://doi.org/10.21747/9789898969217/paraa16

material. Drama attempts to put back some of this forgotten emotional content into language - and to put the body back too. (Maley \& Duff, 1994, p.7)

Aden, a Professor in language sciences, has long studied Varela's research, experimented drama in language classes and examined the cognitive development of language learners through drama within an enactive paradigm. She writes:

Le passage par le jeu théâtral (...) permet notamment d'associer les langues apprises à des coordinations d'actions. En effet, la perception d'un nouveau sens n'est pas simplement mentale, elle est rendue possible par la collaboration du corps et du cerveau en action : le local et le global sont inséparables. (Aden, 2017, p.5)

After thoroughly analyzing Varela's conception of language acquisition, she has concluded that interaction is the place where knowledge emerges.

Varela puts forward the creation of the world through the double flow of action/perception of the subject and his/her environment. This is what he calls "structural coupling". Varela subsequently ventures that if knowledge emerges in the sensorimotor interaction of the subject with his/her environment, it is not pre-determined but it emerges in interaction. Therefore, for Aden, drawing on Varela's theories, the language helps people to determine themselves and others at the same time: it helps people codetermine themselves (Aden, 2017, p.7). Interactions - which trigger socio-cognitive conflicts -, be they oral, physical or both, are thus at the heart of learning and teaching, even when it comes to languages, and drama is a device that provides such interactions. Aden relies on the neuroscientific theory of embodied cognition to study the didactic value of drama in language learning to show how body, mind and emotions all contribute to language acquisition as well as language learning.

More recently, the discovery of mirror neurons by two Italian researchers (Rizzolatti \& Sinigaglia, 2008) has shed light on the capacity of humans to enter into motor resonance and determined how they feel empathy for each other. Aden considers drama as a pedagogical device that permits students and teachers to enter into motor resonance in the classroom and thus makes the feeling of empathy emerge, ultimately creating a positive learning atmosphere.

Following the experiments of Aden in France based on Varela's theories in neuroscience, we decided to verify the impact of drama on language learning and 
PRIVAS-BRÉAUTÉ, Virginie - Drama activities to create a positive language learning environment...

Para lá da tarefa: implicar os estudantes na aprendizagem de línguas estrangeiras no ensino superior.

Porto: FLUP, 2019, pp. 292-309

DOI: https://doi.org/10.21747/9789898969217/paraa16

introduced drama and drama activities to stimulate our students through the creation of a positive learning atmosphere.

\section{4 - Experiments}

Experiments with several profiles of French students studying English were carried out from 2013, the two major ones being a) 30 students completing a bachelor's degree in a Business school in 2015 and b) 45 Masters' degree students in a Department of Languages and Cultures in 2017.

\section{1 - Research Methods}

Both of the experiments presented in this article follow the same research methodology, including respecting the phases when introducing drama in a language lesson. Indeed, three phases should be observed. The first phase is called "the preparation phase" and comprises a) warm-up activities to waken all the senses of the students, b) cohesion games to stimulate students to speak and create a playful atmosphere and interaction among students, c) discovery activities defined as any activity that promotes verbal exchange without interpreting a role, a character, and d) preparatory tasks to prepare the performance phase. Teachers need to devote a long time to these activities to get ready to play. The preparation phase is crucial in that respect: it enables students to become aware of their bodies and their emotions, and to get to know each other from perspectives others than scholarly ones. Moreover, carefully following these activities one week after another helps create some kind of ritual with which students become progressively familiar and confident, which leads to establishing a positive and welcoming atmosphere.

The second phase is known as "the performance phase" which consists of playing roles, embodying characters and being immersed in communication situations in front of the rest of the class. The long preparation phases, offering activities which are different from one week to another, enable students to then act more freely, to be more confident, to trust the others and be free and creative when they play during the performance phases. One of the goals is also to deter fears of judgement by involving every student.

The last phase is "the exploitation phase": students and teacher go back to the sketches they have seen and played and say to the performers what was positive and what was negative, what they liked, what they did not like and justify their comments. This step is important if students want to improve their competences. This is always done in a benevolent atmosphere, the goal being to be constructive and not judge the others 
PRIVAS-BRÉAUTÉ, Virginie - Drama activities to create a positive language learning environment...

Para lá da tarefa: implicar os estudantes na aprendizagem de línguas estrangeiras no ensino superior.

Porto: FLUP, 2019, pp. 292-309

DOI: https://doi.org/10.21747/9789898969217/paraa16

or laugh at them as is explained to them. This step aims at transforming feedback (what students receive) into feedforward (raising awareness about what students need to consolidate to improve). The following model (Figure1) gives a comprehensive outlook at how drama activities can be introduced progressively.

\section{Preparation phase}

\begin{tabular}{|l|l|l|}
\hline $\begin{array}{l}\text { Wam up } \\
\text { activities }\end{array}$ & $\begin{array}{l}\text { Discovery } \\
\text { games }\end{array}$ & $\begin{array}{l}\text { Preparatory activities and tasks } \\
\text { (in a traditional classroom) }\end{array}$ \\
\hline $\begin{array}{l}\text { Non-verbal } \\
\text { Breathing exercises }\end{array}$ & $\begin{array}{l}\text { Articulation of the } \\
\text { verbal and non-verbal }\end{array}$ \\
\hline
\end{tabular}

2. Performance phase

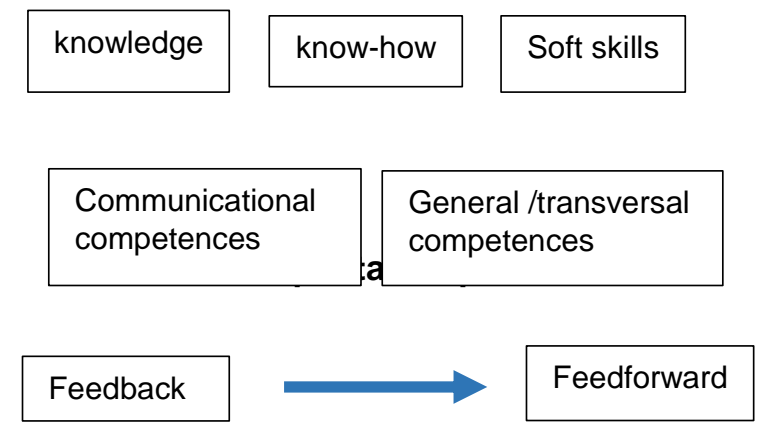

Figure 1. Suggested model of drama activities in language classes. This figure illustrates the steps to introduce drama activities in language classes progressively.

To collect data, our experiments relied on observations of the students during the three phases above mentioned as well as photos and video-recordings of some of the performances of a few students after asking their permission to use them for research purposes. We are still working on the transcriptions of the performances. We also distributed questionnaires after all the courses to get some feedback from the students since we aimed at knowing whether they felt drama activities create a positive learning atmosphere and promote language learning.

\section{2 - Business school students}

The first experiment carried out fell within a pedagogical unit entitled "advertising", covering 14 hours (9 lessons) from January to March 2015. 30 B2 students in a French Business school learning English for specific purposes, that of working in Human Resources, marketing and management, were required to play roles of professional advertising agents. The first 11 hours were spent in a traditional classroom using two 
PRIVAS-BRÉAUTÉ, Virginie - Drama activities to create a positive language learning environment...

Para lá da tarefa: implicar os estudantes na aprendizagem de línguas estrangeiras no ensino superior. Porto: FLUP, 2019, pp. 292-309 DOI: https://doi.org/10.21747/9789898969217/paraa16

textbooks: New Insights into Business (Pearson-Longman, 2001) and English for marketing and advertising (Oxford University Press, 2009). For the remaining three hours, a specific room for artistic rehearsals (dance, drama, music) without furniture was required.

\subsection{1 - The preparation phase}

Our main pedagogical objective was to train students in the five language skills (reading, listening, writing, speaking, interacting) through various activities and tasks such as: brainstorming about advertising; differentiating product, service and corporate advertising; studying slogans and cultural references in slogans (and the problem of translating them); learning about the AIDA strategy (catch the audience's Attention/ make them Interested/ create Desire/ and state the Action the audience should take); creating ads; discovering two companies (Red Arrow and Joys of Germany); placing an order; creating a new ad to attract British people to Germany for their holidays; commissioning a new ad campaign to promote a product; writing an email to let consultants know the decision of the Red Arrow advertising agency; establishing a budget and choosing the right medium to advertise (from a bill of specifications). This preparation phase had thus to do with learning and enriching specific vocabulary, differentiating the methods of advertising and the types of adverts, raising awareness on intercultural differences, mobilizing and reactivating the grammatical structures they know, learning new marketing strategies, pronouncing new words and learning how to write emails and bills of specifications.

The course started with warm-up exercises so as to wake the students' bodies and vocal cords up. After a first series of exercises (walking, stretching and preparing their voices), the students had to engage in cohesion activities. One example of the cohesion activities is given in photograph 1. For this activity, they had to think about the product they had to advertise and pass it along from one student to the next. The product necessarily changed aspects, weights, sizes, which gave rise to a lot of funny transmissions - as the smiles on the students' faces can be seen in photo 1 - and created a relaxed atmosphere. 
PRIVAS-BRÉAUTÉ, Virginie - Drama activities to create a positive language learning environment... Para lá da tarefa: implicar os estudantes na aprendizagem de línguas estrangeiras no ensino superior. Porto: FLUP, 2019, pp. 292-309 DOI: https://doi.org/10.21747/9789898969217/paraa16

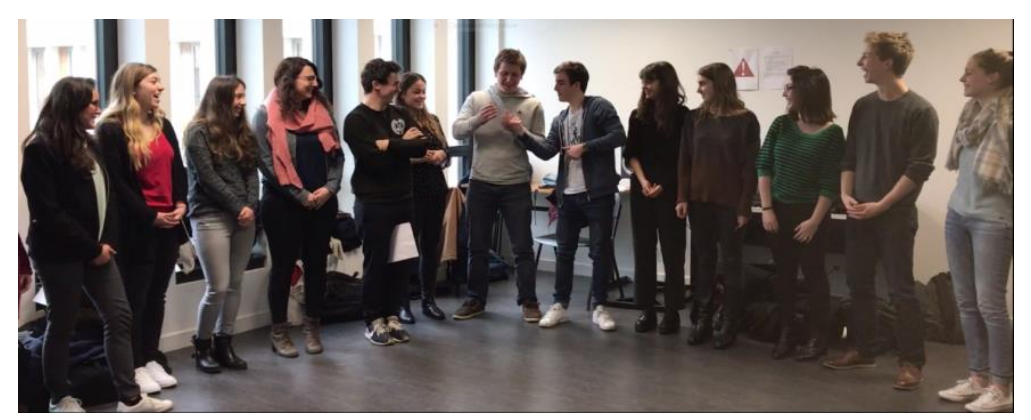

Photo 1. Cohesion activity, passing on the objects. This photo illustrates how to ease the atmosphere.

The last activity falling within the preparation phase had to do with each group preparing their bill of specifications.

\subsection{2 - The performance phase}

Once all the students and groups finished writing their bills of specifications, they approached an advertising agency (the roles and matches were given by the teacher) and placed their order for a new advert either for a product or for a service. When they played the role of the advertising agency, they had to follow the AIDA model. For this phase, they mobilised and reactivated the vocabulary, grammar and methodologies they learnt previously, and they had to use their creativity skills. Once the students had all played the roles both of the clients and of the advertising agents, they had to find the best advert for their clients and make suggestions. For this occasion, the room was equipped with a desk and a few chairs so as to help the students pretend they were professionals working in offices. This task was presented in front of all the other students, who listened carefully to the proposals, checked if the AIDA model was respected and took notes on the attitudes of the professionals-to-be.

\subsection{3 - The feedback phase}

Following the performances of all the groups, the students gave their opinions on the proposals. The teacher remained in the background so as to note down the phonological, grammatical and lexical quality of the students' spoken English and video-tape some presentations. Feedback came from the teacher but also from the other students. It was then possible for two groups to watch the videos (only two groups could be recorded) and become aware of their strengths and weaknesses in light of what the teacher and the other students suggested. From that, students were expected to take a step back from the decisions and proposals they presented (the teacher wrote advice on linguistic improvement for some students) and develop cognitive and metacognitive competences 
PRIVAS-BRÉAUTÉ, Virginie - Drama activities to create a positive language learning environment... Para lá da tarefa: implicar os estudantes na aprendizagem de línguas estrangeiras no ensino superior. Porto: FLUP, 2019, pp. 292-309 DOI: https://doi.org/10.21747/9789898969217/paraa16

from their performances. A questionnaire was then sent to all of them to collect and analyse their impressions on drama as a device to support language learning in a positive learning atmosphere.

\section{3 - Master's degree students}

Another experiment was carried out in 2017 with students from a Department of Languages and Cultures. This group was composed of 45 learners with levels ranging from B2 to $\mathrm{C} 2$ due to their various curricula. Their average age was 25. A third of the students were in-service teachers, the second third was interested in working in tourism, culture, and translation, when the last third was more focused on scientific research in English. All of them were on this course to improve their oral skills in English. They were required to learn and play scenes from a Northern Irish theater play after becoming aware of drama activities to facilitate speaking and listening skills, over a three-month period, comprising six lessons of two hours each. The three phases above mentioned were also respected.

After the course, we received some feedback from students about a) this project, b) what they thought they had learnt and c) how they did so, thanks to a questionnaire we required them to fill in.

\subsection{1 - Preparation phase}

The students discovered the preparation phase through lessons 1 to 4 . After a course on the geographical situation and history of Northern Ireland, we started to create a class ritual with breathing exercises so as to help students concentrate and create a relaxing atmosphere (photo 2), and warm-up activities linked to voice training (such as tonguetwisters) and cohesion activities.

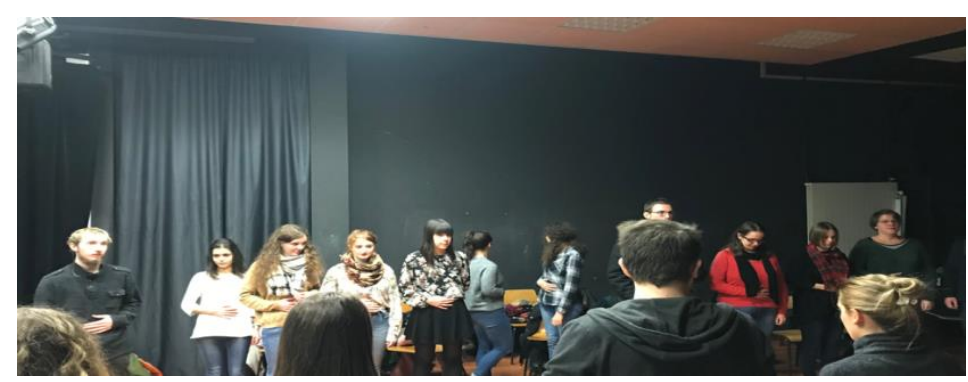

Photo 2. Breathing exercises. This photo illustrates how to concentrate through breathing exercises.

The second lesson had to do with the study of the song "Zombie" by the Cranberries and the analysis of its video clip. This course was focused on the pronunciation of vowels when they are sung or spoken and the difference between Irish and English accents that 
PRIVAS-BRÉAUTÉ, Virginie - Drama activities to create a positive language learning environment... Para lá da tarefa: implicar os estudantes na aprendizagem de línguas estrangeiras no ensino superior. Porto: FLUP, 2019, pp. 292-309 DOI: https://doi.org/10.21747/9789898969217/paraa16

the students had to identify. The students were then required to sing the song all together.

The third lesson had to do with getting to know drama techniques. We first presented the pedagogical value of drama and drama techniques on linguistic, general and professional competences before doing more warm-up exercises, cohesion activities and improvisation role-plays in teams (choosing a topic from the news and interpreting it) requiring them to be creative in communication situations.

The last course of the preparation phase consisted in studying the play. The students discovered the author of the play chosen by the teacher - Ourselves Alone by Anne Devlin (1941) - . Then we introduced a methodology about how to study a play. Students had to pick and analyse a theme (characters, place, time, props, stage directions) before giving oral presentations in groups in front of the class. The teams had to get used to the new space (which was not a traditional classroom) and occupy it all as can be seen in photo 3.

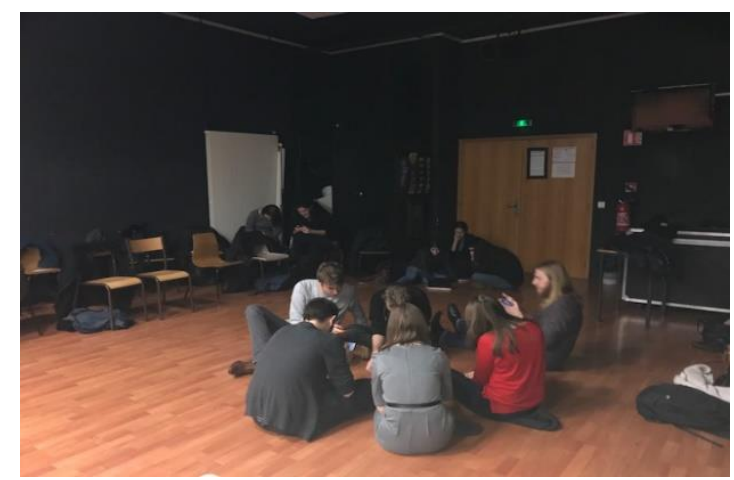

Photo 3. Analysing one theme from a play. This photo illustrates how students managed to occupy the whole unusual space in groups.

\subsection{2 - Performance phase}

After more warm-up, cohesion and preparatory activities in the last two courses, the students had to play scenes from both acts of the play (photo 4). 
PRIVAS-BRÉAUTÉ, Virginie - Drama activities to create a positive language learning environment... Para lá da tarefa: implicar os estudantes na aprendizagem de línguas estrangeiras no ensino superior.

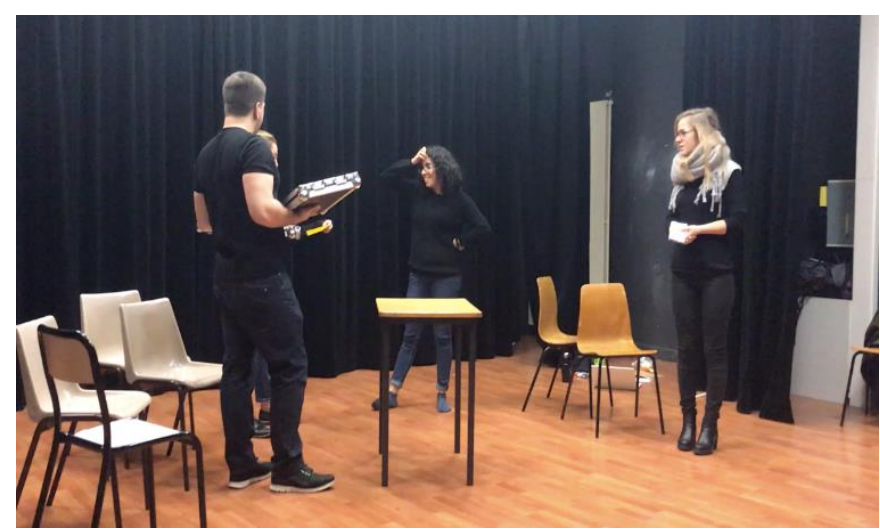

Photo 4. The performance phase. This photo illustrates students playing a scene from Ourselves Alone.

\subsection{3 - Feedback phase}

Since this unit was meant to help students improve their oral skills in English, the teacher as well as the students/ spectators provided feedback after each lesson where the students had to present their work and perform the scenes. The focus was on linguistic, i.e. pronunciation, grammar, vocabulary, but also pragmatic and sociolinguistic competences, and comments were designed to permit learners understand their mistakes and correct them. In parallel, the questionnaire students were given provided the teacher with some information on whether they considered drama and drama techniques as a useful pedagogical device.

\section{5 - Results}

\section{1 - Observations of the teacher}

From what we observed during the performances and in the films taken, we can say that immersing learners in contextualized communicational situations and inviting them to interact in groups led them to dare to speak English.

All the students of both experiments were willing to participate in the drama activities and prepared all the tasks they were assigned. When it was time for them to speak in front of the whole group, no one complained. On the contrary, they showed motivation in playing the roles they were given. Even if some of them were not confident with their level in English, they relied on the other team members to help them correct their mistakes or find the words they lacked. We think that the position of the teacher in such pedagogical situations, that is to say, remaining in the background, listening without 
PRIVAS-BRÉAUTÉ, Virginie - Drama activities to create a positive language learning environment...

Para lá da tarefa: implicar os estudantes na aprendizagem de línguas estrangeiras no ensino superior. Porto: FLUP, 2019, pp. 292-309 DOI: https://doi.org/10.21747/9789898969217/paraa16

interrupting the role-plays and ensuring the "well-learning 1 " of the students, encouraged the learners to correct one another and themselves.

Likewise, we noticed that when they worked in groups, even the shiest students participated in the projects. Students seemed to feel more confident and better equipped linguistically when they worked together.

Then, the use of their bodies came to complete what they said. Not only did students exemplify what they meant, what they said through gestures and facial expressions, but they also dared to mime what they could not express because they lacked words or wanted to express emotions without saying them (being impatient for instance). So, their non-verbal and co-verbal competences were also trained.

A master's degree student told us before the course started that he was too shy to speak in front of a group and that he suffered from a feeling of inferiority, so he was not ready to perform in front of the whole class. We reassured him saying that if he did not want to speak, he could either stay in the background and watch the performances of the other groups, or try to participate and mime his role. However, he tried to embody a character and managed to speak English. We noticed that he was very proud of himself.

\section{2 - Questionnaires}

The questionnaires that the students involved in both experiments filled in after the courses were designed to collect their feelings about drama activities so as to improve language learning and the creation of a positive atmosphere facilitating language learning. The different formats of both questionnaires (one for Business students and another for master's degree students) do not allow us to present quantitative results; yet, their similarity in term of contents provides a closer look at the strengths and weaknesses of drama as a pedagogical device in language classes, with the emphasis on the positive facilitating atmosphere conveyed and the subsequent problems encountered.

\subsection{1 - Strengths of the device}

The first type of advantages that drama brings relates to emotions. A lot of students stated how motivated they felt particularly when the drama games were close to real-life situations (which Viau considers as a criterion of motivation, 2009). They admitted they were enthusiastic ("I am keen on speaking English more from now on ${ }^{2 "}$ ) and could be creative (Aden, 2009, writes that the more creative you can be, the more you speak, and

\footnotetext{
${ }^{1}$ This is a word that we are deliberately inventing.

2 Translated from their comments in French.
} 
PRIVAS-BRÉAUTÉ, Virginie - Drama activities to create a positive language learning environment...

Para lá da tarefa: implicar os estudantes na aprendizagem de línguas estrangeiras no ensino superior. Porto: FLUP, 2019, pp. 292-309 DOI: https://doi.org/10.21747/9789898969217/paraa16

the more you speak, the more creative you are). There was no pressure put upon them (no mark) and the breathing exercises to control stress and concentration helped them enter the activities (André, 2017).

The second type has to do with the use of the language itself. The students said that interactions, be they verbal, non-verbal or co-verbal, encouraged them to engage in the activity, and ultimately, speak more. They also emphasized the absence of precise directions (like in grammar activities for example) which helped them say what they wanted and interpret the roles as they wished. They felt reassured when they could rely on gestures and mimes when no word came ("when we are out of words, we can mime what we want to say") so involving their bodies in the conversations helped them communicate.

The final set of advantages is linked to the environment. Many students realized how the activities were student-centered and some said "usually, we have lessons on phonetics in which we just have to repeat words, sentences, so we are not required to participate so actively" and "we had a lot of practice in real-life situations". They were also pleasantly surprised by the unusual classroom, with very little furniture. One student admitted: "I have been able to improve my ease when speaking English and using space".

\subsection{2 - Weaknesses}

The questionnaires have also thrown some light on the weaknesses that the introduction of drama activities in language classes presents. The most recurring one is linked to emotions. Many students confessed that they felt they were too shy or introverted to participate and speak in front of a group from scratch. Others were not at ease and felt "a lot of stress". This device was too unusual for them and they said they were "not at ease with drama".

Other weaknesses fall within the realm of the use of the language. Some students felt they had not enough creativity while others not enough guidance, so, they did not talk enough or did not feel confident with their level of English. They admitted they should have spoken more since it was an opportunity for them to do so.

Finally, weaknesses linked to the environment highlight the excess of autonomy that some students did not enjoy. All the students complained about the high number of students (many advised to keep the device but to keep the number of students down), about the heterogeneous levels of language proficiency. Some were bothered by the fact these drama activities did not lead to any mark, which can be considered as both a 
PRIVAS-BRÉAUTÉ, Virginie - Drama activities to create a positive language learning environment...

Para lá da tarefa: implicar os estudantes na aprendizagem de línguas estrangeiras no ensino superior.

Porto: FLUP, 2019, pp. 292-309

DOI: https://doi.org/10.21747/9789898969217/paraa16

strength and a weakness depending on the importance we give to quantity over quality or vice versa (see above). Most of them had the impression they did not improve their oral ability because the lessons were too short.

\section{6 - Discussion}

The positive learning environment created by drama activities seems to facilitate language learning and promote speaking.

Playing roles in teams helps learners consolidate their lexical, grammatical and phonological skills. Students often rely on the other team members to help them overcome linguistic obstacles. Verbal, non-verbal and co-verbal interactions among them, studied in light of the body/mind continuum as presented by Varela, lead us to become aware of the cognitive development of the students in language classes. In Le corps dans la langue, les techniques dramatiques dans l'enseignement/apprentissage des langues, Cormanski (1993) writes that the body has such a memory involving emotions and senses that the cognitive function is fully implicated. This leads to learning being retained more, which also echoes the theory of Varela about long-term memorization.

Thanks to the individual comments and advice on the quality of their spoken English that the teacher told them, students are now expected to focus on their personal weaknesses so as to reach communicative autonomy.

In the questionnaires, a few students pointed out the "enthusiasm" and "dynamism" of the teacher animating the drama activities, even if no student wrote the word "empathy", be it in reference to the attitude of the facilitator or to the other learners, and no one hinted at the participation of all the students. This nonetheless shows that some of them - if not all of them - could feel the positive environment that the teacher aimed at creating, which leads us to assert that this contributed to motivating them, facilitating and strengthening their learning.

If drama activities help learners consolidate their communicative competences and improve general competences (they train to be more at ease, they speak freely, learn to manage space and time and to control their bodies and emotions), they must also facilitate the acquisition of professional competences and prepare students for the world of work (Privas-Bréauté, 2016, 2018). The Business students could realise this because their role-plays were in line with their training, yet, many master's degree students did not see the professionalizing dimension of the drama activities and techniques since they tended to focus on the content and not the form of the tasks they were given. 
PRIVAS-BRÉAUTÉ, Virginie - Drama activities to create a positive language learning environment... Para lá da tarefa: implicar os estudantes na aprendizagem de línguas estrangeiras no ensino superior. Porto: FLUP, 2019, pp. 292-309 DOI: https://doi.org/10.21747/9789898969217/paraa16

\section{7 - Conclusion}

These experiments have enabled us to demonstrate that drama activities set up a positive learning environment through the empathy and benevolence of both the teacher and the students (supported by psychological and neuroscientific theories) and ensure their "well-learning". Introducing drama and drama activities in the language classroom can be viewed as a work in progress (Cormanski, 1993), which reflects the absence of linearity in language learning and permits the segmentation of competences that can be built progressively and reactivated constantly. Drama activities foster both linguistic and general competences since learners must complete tasks and communicate more and better. Role-plays and drama techniques also progressively lead them to build professional abilities that can be then transferred to real life and real situations. Training learners speak English through drama activities eventually helps them lessen the anxiety, stress and fear they may feel when they must express themselves in this foreign language.

However, in light of the weaknesses put forward by the students, we would recommend primary school and secondary school teachers to start introducing drama and role-play in primary schools in France so as to help pupils get used to performing in front of an audience and gain self-confidence very early on: speaking a language is not only about knowing how to complete tasks successfully, it also has to do with learning how to relate to other human beings and interact.

\section{References}

Aden, J. (2009). La créativité artistique à l'école: refonder l'acte d'apprendre. Synergies Europe, 4, 173-180.

Aden, J. (2017). Langues et langage dans un paradigme enactif. Recherches en didactique des langues et des cultures, 14.1. Available at http://rdlc.revues.org/1085. Accessed 21 March 2017.

André, C. (2017). Méditez avec nous. Paris: Éditions Odile Jacob.

Arnold, J. (1999). Affect in Language Learning. Cambridge: Cambridge University Press.

Cormanski, A. (1993). Le corps dans la langue. Les techniques dramatiques dans l'enseignement/apprentissage des langues. Unpublished $\mathrm{PhD}$ thesis. Université de la Sorbonne Nouvelle, Paris 3. 
PRIVAS-BRÉAUTÉ, Virginie - Drama activities to create a positive language learning environment...

Para lá da tarefa: implicar os estudantes na aprendizagem de línguas estrangeiras no ensino superior. Porto: FLUP, 2019, pp. 292-309 DOI: https://doi.org/10.21747/9789898969217/paraa16

Horwitz, E. K., Horwitz, M. B. \& Cope, J. A. (1986). Foreign Language classroom anxiety. Modern Language Journal. 70.2, 125-132.

Krashen, S. (1982). Principles and Practice in Second Language Acquisition. Oxford: Pergamon Press.

Maley, A. \& Duff, A. (1994). Drama Techniques in Language Learning. A Resource Book of Communication Activities for Language Teachers. Cambridge: Cambridge University Press.

Paradis, M. (1994). Neurolinguistic aspects of implicit and explicit memory: Implications for bilingualism. In N. Ellis, N. C. (ed.), Implicit and explicit learning of Second Languages. London: Academic Press, 393-419.

Privas-Bréauté, V. (2016). L'apprentissage de l'anglais par le jeu dramatique et les techniques dramatiques en IUT : dispositifs de professionnalisation et de socialisation. Lingua E Nuova Didattica, Approcci teatrali nella didattica delle lingue. Parola, corpo, creazione, 93-119.

Privas-Bréauté, V. (2018). Le jeu et les techniques dramatiques en classe de langue : Un levier pour la co-construction des compétences professionnelles. Mélanges CRAPEL, 38/2, 77-93.

Rizzolatti, G. \& Sinigaglia, C. (2008). Les Neurones Miroirs. Paris: Editions Odile Jacob.

Rogers, C. (1969). Freedom to learn: A view of what education might become. Columbus: Charles E. Merrill.

Schumann, J. (1994). Where is cognition? Studies in Second Language Acquisition, 16, 231-242.

Trocmé-Fabre, H. (1994). "Né pour créer du sens avec Francisco Varela". Available at

https://www.canalu.tv/video/cerimes/ne_pour_creer_du_sens_avec_francisco_varela.1 2824 Accessed 24 May 2016.

Varela, F., Thompson, E. \& Rosch, E. (1993). L'inscription corporelle de l'esprit, Sciences cognitives et expérience humaine. Paris: Editions du Seuil.

Varela, F. (1996). Invitation aux sciences cognitives. Paris: Editions du Seuil.

Viau, R. (2009). La Motivation en contexte scolaire. Paris: Editions de Boeck. 